Research article

\title{
A new species as a member of the Flora of Turkey: Persicaria hydropiperoides (Polygonaceae)
}

\author{
Mustafa Keskin*1 (iD, Zeki Severoglu² iD \\ ${ }^{1}$ Marmara University, Institute of Pure and Applied Sciences, Biology Program, 34722, Goztepe, Istanbul, Turkey \\ ${ }^{2}$ Marmara University, Faculty of Science \& Arts, Department of Biology, 34722, Goztepe, Istanbul, Turkey
}

\begin{abstract}
Persicaria genus in Turkish Madımakgiller or Buckwheat family (Polygonaceae) is included in the genus Polygonum now. Today, the genus Persicaria is separated from the genus Polygonum. In this study, Pe. hydropiperoides belonging to the genus Persicaria is given as a new species for the flora of Turkey. Specimens of Pe. hydropiperoides were collected from Sancaktepe/ Paşaköy (Istanbul). Adding this new species, the number of Persicaria genus in Turkish Flora reached 12 species (13 taxa). Additionally, a Turkish name, detailed description, locality data, photographs, and geographical distribution information of the species were given in this research.
\end{abstract}

Keywords: A new record; Istanbul; Pe. hydropiperoides; Persicaria; Turkey

\section{Introduction}

Polygonaceae Juss (Buckwheat in English or Madımakgiller in Turkish), which contains around 50 genera and 1200 species worldwide, is usually found in temperate zones of the Northern Hemisphere and is only rarely found in tropical climates (Heywood, 1978; Freeman and Reveal, 2005).

Except for the subfamily Erigonuideae Meisner, the most common trait of this family is the presence of the ocrea (a stipule modification that wraps around the stem).

According to recent investigations, the number of taxa grew by 11 in Polygonaceae, the Flora of Turkey, and the Eastern Aegean Islands (Davis et al., 1967; Coode and Cullen, 1967). (Keskin, 2012; Karaer et al., 2020). Persicaria (L.) Miller, on the other hand, was originally assessed in Polygonum L. in 1754, however, Miller (1754) split it as a new genus. With the splitting of Persicaria from Polygonum in recent years, Turkey now possesses 12 genera (Brandbyge, 1993; Keskin and Severoglu, 2020).

In Polygonum, the ocrea is normally membranous, silvery, and glabrous, with a two-lobed apex that is typically fibrous and glabrous. The ocrea tube of Persicaria is not membranous, but rather fleshy, brown or reddish, rarely silvery, hairy, or glabrous, seldom 2-lobed at the tip, and frequently ripped apart by aging (Webb and Chater, 1964; Davis et al., 1967; Hinds and Freeman, 2020).

\section{Materials and methods}

Persicaria samples were gathered from the Anatolian side of Istanbul in November 2019 during field investigations conducted by the first author as a part of his doctoral dissertation research.

Examples, the former name Polygonum hydropiper at first appearance, the current name $P e$. hydropiper although it resembles 'hydropiper', as a result of detailed examination, it is an unknown species from Turkey belonging to the genus Persicaria; as a result of the literature study (Webb and Chater, 1964; Small, 1895) and herbarium (E, EGE, ISTE, ISTF, ISTO, ANK, MUFE and NGBB).

\section{* Corresponding author.}

E-mail address: trifolium@ @otmail.com (M. Keskin). https://doi.org/10.51753/flsrt.951412 Author contributions

Received 12 June 2021; Accepted 28 October 2021

Available online 15 December 2021

2718-062X (C) 2021 This is an open access article published by Dergipark under the CC BY license. 
The gathered samples are stored at MUFE (Marmara University Faculty of Arts and Sciences Herbarium).

\section{Results}

Linne named Persicaria as a member of the Polygonum genus because it looks to have peach (Persica) leaves (Linne, 1753). Miller later classified it as a distinct genus (Miller, 1754). With this record, Persicaria has 150 species worldwide (Hinds and Freeman, 2020) and 12 species in Turkey.

\subsection{Persicaria hydropiperoides (Michaux) Small, Fl. S.E. U.S.} 378, 1330 (1903). (Fig. 1 and 2).

Basionym: Polygonum hydropiperoides Michaux, Fl. Bor.-Amer. 1: 239 (1803).

Synonyms (according to Hinds and Freeman, 2005): Persicaria opelousana (Riddell) Small, Fl. S.E. U.S. 378, 1330 (1903). P. hydropiperoides subsp. opelousanum (Riddell) W.Stone, Pl. S. New Jersey 422 (1912). P. hydropiperoides var. psilostachyum H.St.John, Proc. Boston Soc. Nat. Hist. 36: 71 (1921). P. hydropiperoides var. digitatum Fernald, Rhodora 23: 260 (1922). P. hydropiperoides var. asperifolium Stanford, Rhodora 28: 27 (1926). P. hydropiperoides var. bushianum Stanford, Rhodora 28: 27 (1926). P. opelousanum var. adenocalyx Stanford, Rhodora 28: 28 (1926). Pe. paludicola Small, Man. S.E. Fl. 457 (1933). P. hydropiperoides var. breviciliatum Fernald, Rhodora 42: 448 (1940). $P$. hydropiperoides var. adenocalyx (Stanford) Gleason, Phytologia 4: 23 (1952). Pe. hydropiperoides var. euronotorum (Fernald) C.F.Reed, Phytologia 50(7): 461 (1982). Pe. hydropiperoides var. breviciliata (Fernald) C. F. Reed, Phytologia 50: 461 (1982). Pe. hydropiperoides var. bushiana Mohlenbr., Vasc. Fl. Illinois 501 (2014), nom. inval. Pe. hydropiperoides var. bushiana (Stanford) Mohlenbr, Phytoneuron 2015-67: 3 (2015). Pe. hydropiperoides var. strigosa (Small) G.Wilh. \& Rericha, Michigan Bot. 55(3-4): 95 (2016).

Type locality: in Pennsylvania, Virginia, Carolina.

Life span: Perennials with rhizomes.

Stems: (15-)35-45(-100) cm long; decumbent to ascending, usually branched, without ribs, glabrous; usually branched or single; brownish or colorless, sparsely glandular; the glands are prominent after the central part of the body, reddish-brown in the lower part; the internodium is variable but body-like in structure.

Leaves: Ocrea in the middle of the stem, swollen base, (5)15-20(-23) mm, brown, at the tip, truncate, ciliated with bristles (2-)4-5(-10) mm, white; ocrea tube 10-nerved, end of each vein with reddish brownish cilia, fragile. Petioles $(2-) 5-8(-20) \mathrm{mm}$, glabrous or strigose; blade 40-80(-250) x (4-)10-18(-35) mm, no blocth, linear to lanceolate, acuminate to caudate and obtuse at apex; the main vein evident on the upper face, both the main vein and the lateral veins are prominent on the lower face with strigose on edge.

Inflorescences: $(30-) 50-100 \times 2-5 \mathrm{~mm}$, terminal, sometimes also axillary, erect, or curved. Bracts 8-15 x 1-3 mm, lanceolate, like a leaf. Peduncles $7-40 \mathrm{~cm}$, usually as long as inflorescences; glabrous or strigose; ocreol usually overlapping distally, margins ciliate with bristles to $2-3 \mathrm{~mm}$.

Flowers: Pedicels 1-3.5 mm, shorter than ocrea, and wrapped by ocreol; bisexual or unisexual and staminate, (2-)45(-6) per ocreate fascicle. Tepals 5; bisexual flowers 2,1-3,2(4) $\mathrm{mm}$, and staminate flowers $1.5-2.5 \mathrm{~mm}$ greenish with pinkish tips or whitish (sometimes rose clour); at maturity the lobes overlap; surface brownish or colorless glandular, usually rather dense, narrow margins, membranous, blunt tip; the veinless surface is adjacent at the base at approximately 1/3-1/2 of the length of the tepals. Stamen 8 , anthers pink or red, elliptic to ovate. Styles 3.

Achenes: Included or apex subexserted, brown to brownish-black or black, 3-gonous, (1.5-) 2.8-3 × 1-2 (-2.5) mm, shiny, smooth.

Flowering time: 7-9 months.

Fruiting time: 9-11 months. Moist roadsides, wet habitats.

\section{Plant Sample Collected:}

Turkey: Istanbul, Sancaktepe, Paşaköy, center, in valley, fountain area, wet place, $\mathrm{N} 41^{\circ} 03^{\prime} 49.7^{\prime \prime}$ and E 28 44' 57.4", 23.ix.2019, M. Keskin 7899!.

Turkish name: Koca evelek (proposal)

$P e$. hydropiperoides were discovered at Sancaktepe/ Paşaköy (Istanbul). It is spread throughout semi-natural landscapes, residential areas, valleys, and marshes. This species associated with a wide range of plants in its environment: Colchicum chalcedonicum subsp. chalcedonicum, Galatella linosyris, Erica manipuliflora, E. arborea, Cistus creticus, C. salviifolius, Prunella vulgaris, Salvia forskahlei, Paspulum paspoloides.

\subsection{Identification key for perennial Persicaria in Turkey}

1. Aquatic, rarely terrestrial; stamens longer than tepal

1. Terrestrials; stamens shorter than tepal amphibia

2. Stems loosely prickled; loosely rooting at nodes (perennant) thunbergii

2. Stems smooth; strongly rooting at nodes (net perennials)

$$
\begin{array}{lr}
\text { 3. Tepal glabrous } & \text { decipiens } \\
\text { 3. Tepal glandular } & \text { hydropiperoides }
\end{array}
$$

A visual comparison of mentioned perennial Persicaria species is given in Fig. 3.

\section{Discussion}

Although it is expected that Pe. hydropiperoides extend across a larger region than the $2-3 \mathrm{~km}^{2}$ region where the samples were gathered. It has a wider spread than this single record since it may have been misidendificated among similar herbarium specimens. Pe. hydropiperoides is one of the species with a great number of (16) synonyms, and it is frequently misnamed due to its high variety and worldwide distribution. The inaccuracy rate increases, especially when identifying without seeing all of the plant's organs (Table).

When a diagnosis is established without removing the subterranean parts, the genus Persicaria is frequently referred to as Pe. maculosa. Pe. hydropiperoides achenes are all triangular prismatic, Pe. maculosa achenes are triangular and two-faced, and ocreae have somewhat longer hairs on the borders (Hinds 


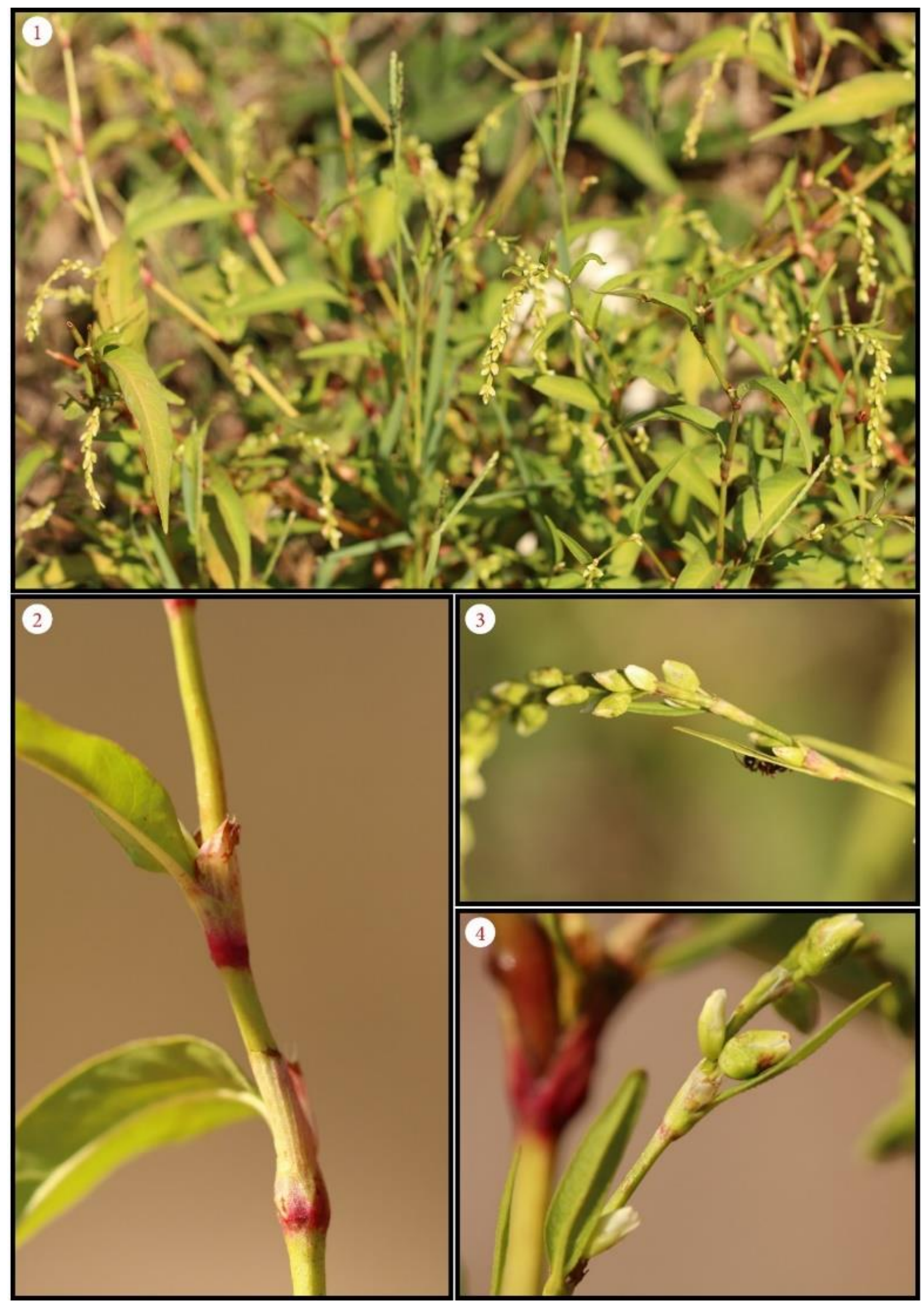

Fig. 1. Persicaria hydropiperoides, (1) Habitus, (2) Internodium, ocrea and base of leaf, (3) Inflorescence and (4) Infructescence. 


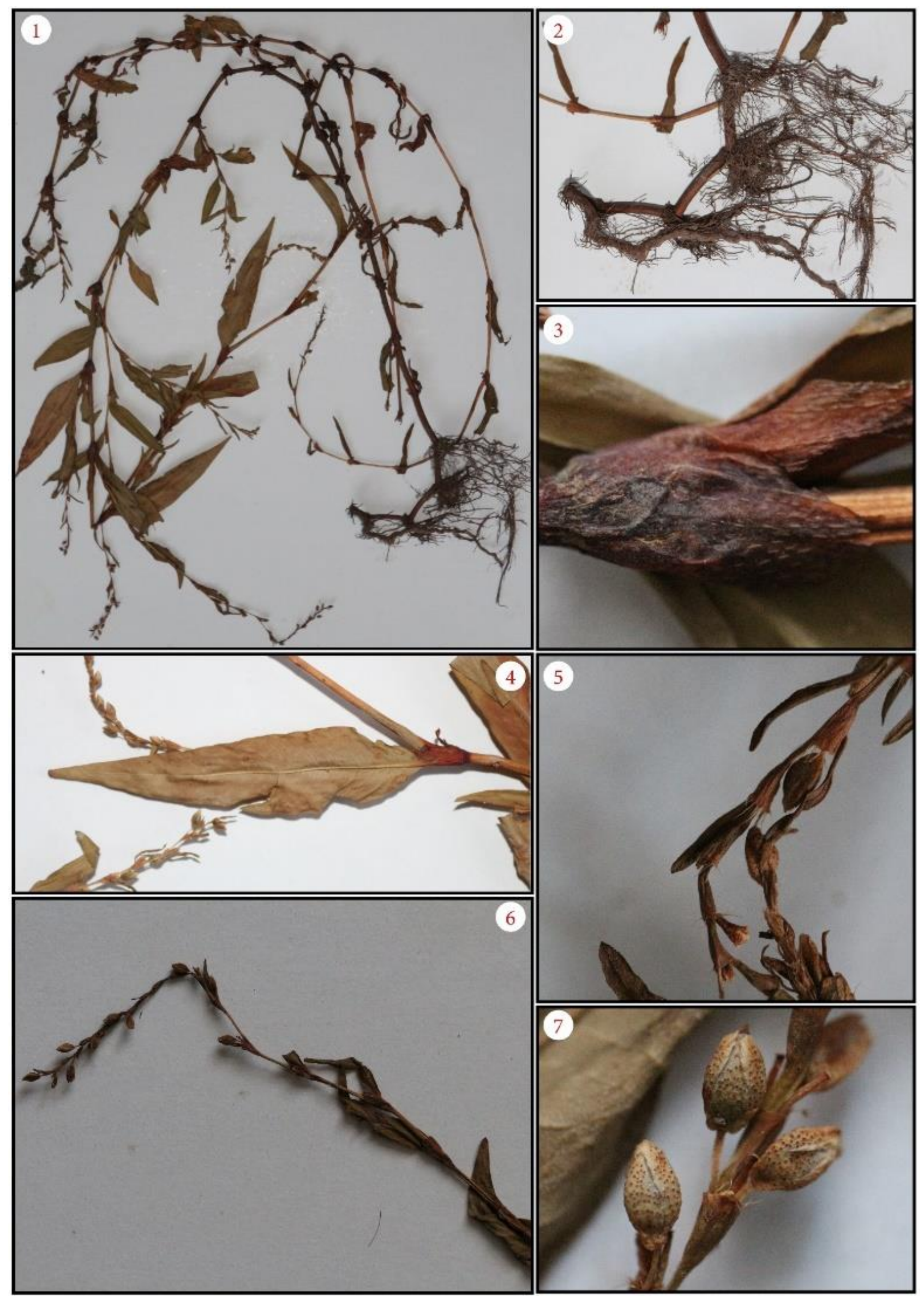

Fig. 2. Persicaria hydropiperoides, (1) General view, (2) Rhizome, (3) Ocrea, (4) Leaf, (5) Inflorescence with staminate flowers, (6) Inflorescence with bracts and upper leaves and (7) Fruiting perianth. 


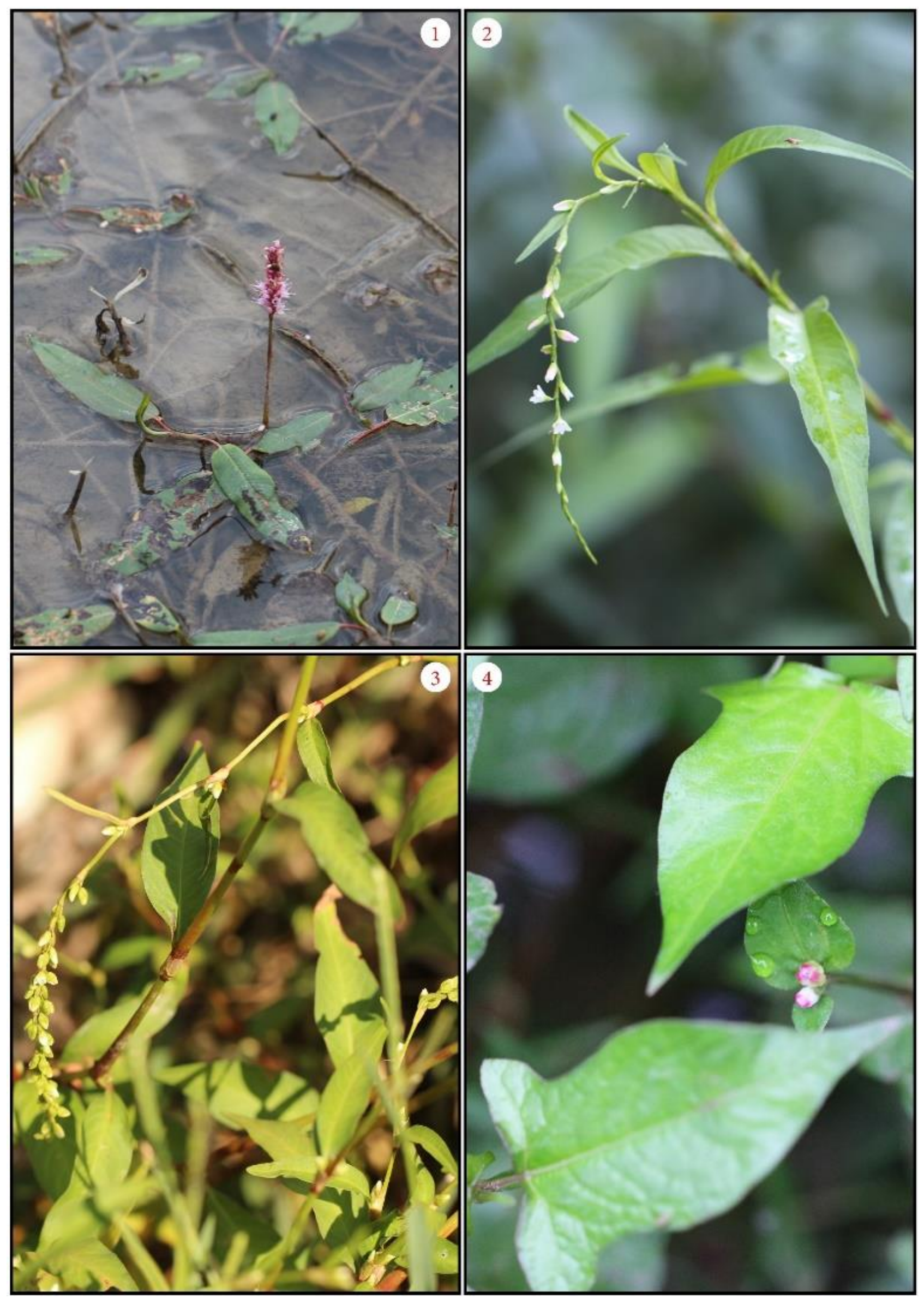

Fig. 3. Perennial Persicaria species, (1) Pe. amphibia, (2) Pe. decipiens, (3) Pe. hydropiperoides, (4) Pe. thunbergii. 
Table

A taxonomic comparison of Pe. hydropiperoides and its allies.

\begin{tabular}{|c|c|c|c|c|}
\hline & $\begin{array}{l}\text { hydropiperoides } \\
\text { (This Article) }\end{array}$ & $\begin{array}{c}\text { hydropiperoides } \\
\text { (Hinds \& Freeman 2020). }\end{array}$ & $\begin{array}{c}\text { hydropiper } \\
\text { (Hinds \& Freeman 2020). }\end{array}$ & $\begin{array}{c}\text { maculosa } \\
\text { (Hinds \& Freeman 2020). }\end{array}$ \\
\hline Life Span & Perennial with rhizomes & Perennial with rhizomes & Annual, rhizomes absent & Annual, rhizomes absent \\
\hline Stem Length & $35-45 \mathrm{~cm}$ & $15-100 \mathrm{~cm}$ & $20-100 \mathrm{~cm}$ & $5-130 \mathrm{~cm}$ \\
\hline Stems & $\begin{array}{l}\text { Decumbent to ascending, } \\
\text { without ribs, glabrous }\end{array}$ & $\begin{array}{l}\text { Decumbent to ascending, } \\
\text { without ribs, glabrous/obscurely } \\
\text { strigose distally }\end{array}$ & $\begin{array}{l}\text { Decumbent to ascending/erect, } \\
\text { branched, without ribs, } \\
\text { glabrous, glandular-punctate }\end{array}$ & $\begin{array}{l}\text { Procumbent, decumbent, } \\
\text { ascending, without ribs, } \\
\text { glabrous/appressed-pubescent }\end{array}$ \\
\hline Ocrea & $\begin{array}{c}\text { Brown, base inflated, } 10- \\
\text { nerved, } 15-20 \mathrm{~mm} \text {; surface } \\
\text { strigose; with bristles } 2-4 \mathrm{~mm}\end{array}$ & $\begin{array}{l}\text { Brown, base inflated, } 5-23 \mathrm{~mm} \text {; } \\
\text { surface glabrous/strigose, with } \\
\text { bristles (2-) } 4-10 \mathrm{~mm}\end{array}$ & $\begin{array}{l}\text { Brown, base somewhat inflated } \\
\text { surface glabrous/strigose, } \\
\text { usually glandular-punctate. }\end{array}$ & $\begin{array}{l}\text { Light brown, base inflated, 4-10 } \\
\text { (-15) mm; surface } \\
\text { glabrous/strigose. }\end{array}$ \\
\hline Petiole & 5-8 mm, glabrous/strigose & 2-20 mm, glabrous/strigose & 1-8 mm, glandular-punctate & $\begin{array}{l}\text { Sessile or } 0.1-0.8 \mathrm{~cm}, \\
\text { glabrous/strigose }\end{array}$ \\
\hline Leaves & $\begin{array}{l}\text { Blotch absent; lanceolate/linear } \\
\text { to lanceolate, } 4-8 \text { x 1-2 cm, } \\
\text { faces glabrous; margins } \\
\text { appressed- hirsute; apex } \\
\text { acuminate to caudate }\end{array}$ & $\begin{array}{c}\text { Blotch absent; broadly } \\
\text { lanceolate to linear-lanceolate, } \\
5-25 \times 0.4-3.7 \mathrm{~cm} \text {, margins } \\
\text { antrorsely appressed-pubescent, } \\
\text { apex acuminate }\end{array}$ & $\begin{array}{l}\text { Blotch absent; lanceolate to } \\
\text { narrowly rhombic, }(1.5-) 4-10(- \\
15) \times 0.4-2.5 \mathrm{~cm} \text {, margins } \\
\text { antrorsely strigose, apex acute } \\
\text { to acuminate }\end{array}$ & $\begin{array}{l}\text { Blotch present; adaxially, } \\
\text { lanceolate to narrowly ovate, } \\
(1-) 5-10(-18) \times(0.2-) 1-2.5(-4) \\
\text { cm, margins antrorsely strigose, } \\
\text { apex acute to acuminate }\end{array}$ \\
\hline Inflorescences & $\begin{array}{c}\text { Terminal, sometimes axillary, } \\
50-100 \times 2-5 \mathrm{~mm}\end{array}$ & $\begin{array}{l}\text { Terminal, sometimes also } \\
\text { axillary, } 30-80 \times 2-5 \mathrm{~mm}\end{array}$ & $\begin{array}{l}\text { Terminal and axillary, } 30-180 \times \\
5-9 \mathrm{~mm}\end{array}$ & $\begin{array}{c}\text { Terminal and axillary, 10-45(- } \\
60) \times 7-12 \mathrm{~mm}\end{array}$ \\
\hline Peduncle & $7-40 \mathrm{~cm}$ & $10-30 \mathrm{~mm}$ & (0-) $10-50 \mathrm{~mm}$ & $10-50 \mathrm{~mm}$ \\
\hline Pedicels & $1-3.5 \mathrm{~mm}$ & $1-1.5 \mathrm{~mm}$ & $1-3 \mathrm{~mm}$ & $1-2.5 \mathrm{~mm}$ \\
\hline Flowers & $\begin{array}{l}\text { Bisexual, } 3-5 \text { per ocreate } \\
\text { fascicle, homostylous }\end{array}$ & $\begin{array}{c}\text { Bisexual/unisexual and } \\
\text { staminate, homostylous, 2-6 per } \\
\text { ocreate fascicle }\end{array}$ & $\begin{array}{l}\text { 1-3(-5) per ocreate fascicle, } \\
\text { homostylous }\end{array}$ & $\begin{array}{c}\text { 4-14 per ocreate fascicle, } \\
\text { homostylous }\end{array}$ \\
\hline Perianth & $\begin{array}{l}\text { Greenish/white with glandular- } \\
\text { punctate on tubes and inner } \\
\text { tepals; tepals } 5,2.1-4 \mathrm{~m} \text {; } \\
\text { staminate flowers } 1.5-2.5 \mathrm{~mm} \text {, } \\
\text { veins not visible; margin entire, } \\
\text { apex obtuse }\end{array}$ & $\begin{array}{l}\text { Roseate proximally, roseate, } \\
\text { White/greenish white distally; } \\
\text { tepals 5, } 2.5-4 \mathrm{~mm} \text { in bisexual } \\
\text { flowers, } 1.5-2.5 \mathrm{~mm} \text { in } \\
\text { staminate flowers; veins } \\
\text { prominent/not, margins entire, } \\
\text { apex obtuse to rounded. }\end{array}$ & $\begin{array}{c}\text { Greenish proximally, } \\
\text { White/pink distally, glandular- } \\
\text { punctate; tepals } 4-5 \text {, obovate, } 2- \\
3.5 \mathrm{~mm} \text {, veins prominent/not, } \\
\text { apex obtuse }\end{array}$ & $\begin{array}{c}\text { Greenish white proximally and } \\
\text { roseate distally/entirely roseate, } \\
\text { not glandular-punctate, scarcely } \\
\text { accrescent; tepals } 4-5 \text {, obovate, } \\
2-3.5 \mathrm{~mm} \text {, veins prominent, } \\
\text { apex obtuse }\end{array}$ \\
\hline Stamens & $\begin{array}{l}8 ; \text { anthers pink to reddish, } \\
\text { ovate- spheroidal }\end{array}$ & $\begin{array}{c}8 \text {; anthers pink/red, elliptic to } \\
\text { ovate }\end{array}$ & $\begin{array}{c}\text { 6-8; anthers pink/red, elliptic to } \\
\text { ovate }\end{array}$ & 4-8; anthers yellow/pink, ovate \\
\hline Achenes & $\begin{array}{c}\text { 3, connate at base area } \\
\text { Brownish to blackish/black, } 3 \text { - } \\
\text { gonous; } 2.8-3 \mathrm{~mm} \text {, shiny, } \\
\text { smooth }\end{array}$ & $\begin{array}{l}\text { 3, connate near middle. } \\
\text { Brown to brownish black/black, } \\
\text { 3-gonous, } 1.5-3 \mathrm{~mm} \text {, shiny, } \\
\text { smooth }\end{array}$ & $\begin{array}{l}\text { 2-3, connate proximally. } \\
\text { Brownish black, biconvex/3- } \\
\text { gonous, } 1.9-3 \mathrm{~mm} \text {, dull, } \\
\text { minutely roughened }\end{array}$ & $\begin{array}{c}\text { 2-3, connate proximally } \\
\text { Brownish black to black, } \\
\text { discoid/biconvex to 3-gonous, } \\
\text { (1.9-)2-2.7 mm, shiny, smooth }\end{array}$ \\
\hline
\end{tabular}

and Freeman, 2021). However, the inflorescence of Pe. hydropiperoides and Pe. hydropiper are identical. Mosaferi and Keshavarzi (2010) described Pe. hydropiperoides as a new record for Iranian flora and conducted a comparative anatomical investigation with species similar to the species. With the registration in Turkey, the distribution of this species from Asia to Europe has been completed. This species is certain to be an invasive species.

Acknowledgments: We kindly thank to the herbarium staff of

\section{References}

Brandbyge, J. (1993). Polygonaceae. In: Kubitzki, K. (ed); Rohwer J.G. and Bittrich V. (vol. eds). The Families and Genera of Vascular Plants volume II (pp. 531-544). Springer-Verlag, Berlin, Heidelberg, Germany.

Coode, M. J. E. \& Cullen, J. (1967). Polygonum L. In: Davis, P. H. et al. (eds), The Flora of Turkey and the East Aegean Islands vol. 2 (pp. 269281). Edinburgh Univ. Press.

Davis, P. H., Cullen, J. \& Coode, M. J. E. (1967). Polygonaceae. The Flora of Turkey and the East Aegean Islands Vol. 2. (pp. 265-293). Edinburgh Univ. Press.

Freeman, C. C. \& Reveal, J. L (2005). Flora of North America Polygonaceae. Vol. 5. (pp. 216-221). Oxford University Press, Oxford. Heywood, V. H. (1978). Flowering Plants of the World (pp. 1-336). Oxford University Press, Oxford.
E, ISTE, ISTF, ISTO, ANK, NGBB, and MUFE for examining the Polygonum and Persicaria specimens and the ANG foundation for their financial support to the Edinburgh trip.

Conflict of interest: The authors declare that they have no conflict of interests.

Informed consent: This manuscript did not involve human or animal participants; thus informed consent was not collected.

Hinds, H. R. \& Freeman, C. C. (2005). Persicaria (Linnaeus) Miller. Flora of North America. http://www.efloras.org/florataxon.aspx? flora_id=1\&taxon_id=250037826. http://flora northamerica.org/ Persicaria_hydropiperoides Last accessed on December 15, 2021.

Karaer, F., Terzioğlu S., \& Kutbay, H.G. (2020). A new genus record forthe Flora of Turkey: Reynoutria (Polygonaceae). KSU Journal of Agriculture and Nature, 23 (3): 606-610.

Keskin, M. \& Severoglu, Z. (2020). The genus Persicaria (Polygonaceae) in Turkey with a new taxon record. EMU Journal of Pharmaceutical Sciences, 3(2), 97-105.

Keskin, M. (2012). Polygonum L. In: Güner A., Aslan S., Ekim T., Vural M., Babaç M. T. (eds.) Türkiye Bitkileri Listesi (Damarlı Bitkiler) (pp.757-764). Nezahat Gökyiğit Bahçesi ve Flora Araştırmaları Derneği Yayını, İstanbul. 
Linne, C. (1753). Species plantarum: exhibentes plantas rite cognitas ad genera relatas, cum diferentiis specificis, nominibus trivialibus, synonymis selectis, locis natalibus, secundum systema sexuale digestas. Tomus I, Holmiae (pp.1-360).

Miller, P. (1754). The Gardeners Dictionary: containing the methods of cultivating and improving all sorts of trees, plants, and flowers, for the kitchen, fruit, and pleasure gardens, as also those which are used in medicine : with directions for the culture of vineyards, and making of wine in England : in which likewise are included the practical parts of husbandry ...4th ed., corrected and enlarged. London.
Mitchell, S. (1971) Comparative leaf structure of aquatic Polygonum species. American Journal of Botany, 58, 342-360.

Mosaferi, M. \& Keshavarzi, M. (2010). Micromorphology and first record of Persicaria hydropiperoides (Polygonaceae) in Iran. Journal of Taxonomy and Biosystematics, 1(2), 63-72.

Small, J. K. (1895). A Monograph of the North American Species of the Genus Polygonum Lancaster, Pa., The New Era Print.

Webb, D. \& Chater, A. (1964). Polygonum L. In: Tutin et al. (eds.). Flora Europaea vol. 1. (pp.76-80). Lycopodiaceae to Platanaceae. Cambridge University Press, Cambridge, UK.

Cite as: Keskin, M. \& Severoglu, Z. (2021). A new species as a member of the Flora of Turkey: Persicaria hydropiperoides (Polygonaceae). Front Life Sci RT, 2(3), 85-91. 